\title{
Genomic imprinting in diabetes
}

\author{
Braxton D Mitchell* and Toni I Pollin
}

\begin{abstract}
Genomic imprinting refers to a class of transmissible genetic effects in which the expression of the phenotype in the offspring depends on the parental origin of the transmitted allele. The DNA from one parent may be epigenetically modified so that only a single allele of the imprinted gene is expressed in the offspring. Although imprinting has an important role in the regulation of growth and development through its role in regulating gene expression, its contribution to susceptibility to common complex disorders is not well understood. We summarize current views on the role of imprinting in diabetes and in particular chromosome 6q24-related transient neonatal diabetes mellitus, the best known example of an imprinted genetic disorder that leads to diabetes.
\end{abstract}

\section{Introduction}

The past 2 years have been marked by the discovery of some 30 new genes associated with type 2 diabetes mellitus (T2DM) and 40 associated with type 1 diabetes mellitus (T1DM) [1,2]. These have been discovered by association studies using very large sample sizes, and the susceptibility alleles discovered are associated with modest increases in diabetes risk of 10 to $20 \%$. Expression of these risk alleles is probably influenced by the presence of other diabetes risk factors, such as lifestyle, viral exposures and perhaps other genetic variants.

In addition to the susceptibility genes identified through conventional association studies, a small number of diabetes-associated genes has been discovered whose effects are mediated through imprinting. Imprinting is a type of genetic effect characterized by parent-to-offspring transmission whereby the expression of the phenotype in the offspring depends on whether the transmission originated from the mother or father. In imprinting, one allele of a specific gene is silenced (through epigenetic

*Correspondence: bmitchel@medicine.umaryland.edu

Division of Endocrinology, Diabetes and Nutrition, University of Maryland, 6601 West Redwood Street, Baltimore, MD 21201, USA mechanisms such as methylation) when inherited from one parent but expressed when inherited from the other. Thus, phenotype expression of imprinted genes is a consequence not only of sequence variation per se, but also of methylation and histone modifications that silence one allele, allowing a normal state of monoallelic gene expression without altering DNA sequence. The consequence of the imprinting phenomenon for association studies is that sequence variation in only the expressed allele will influence phenotype, manifesting in a seemingly non-classical transmission or inheritance pattern that may obscure any genotype-phenotype association. Variants that disrupt normal imprinting may also influence the nature of observed associations. Thus, accounting for the parent of origin of each allele at an imprinted locus should enhance the ability to identify susceptibility variants.

Imprinted genes are in fact only one mechanism through which transmission of disease risk from parent to offspring may be influenced by the sex of the parent transmitting the susceptibility factor. Other mechanisms underlying parent-of-origin effects include mitochondrial transmission and maternal effects attributable to the intrauterine environment [3]. Mitochondrial transmission, for example, is a specific type of parent-of-origin effect resulting from the fact that mitochondria, and therefore sequence variation therein, are transmitted from the mother but not the father to the offspring. Although relatively rare, clear examples of maternally inherited diabetes attributable to deletions or mutations in the mitochondrial genome have been documented [4-6], are often accompanied by deafness, and may account for as much as $1 \%$ of the overall diabetes burden [7]. Mitochondrial transmission is different from disease susceptibility genes that are transmitted on autosomes but which are expressed in the offspring in a sex-specific manner. Examples of autosomally transmitted alleles whose expression is modified by sex of the offspring are the $B R C A 1$ and $B R C A 2$ risk alleles associated with breast (and other forms of) cancer. Although risk of breast cancer is significantly enhanced in both male and female offspring who inherit $B R C A 1$ and $B R C A 2$ risk alleles, the actual risk will be much higher in female offspring. In contrast to imprinting, however, disease risk in this example is influenced by the sex of the offspring as 
opposed to the sex of the parent transmitting the risk allele. A third class of parent-of-origin effect relates to maternal effects attributable to the intrauterine environment. Fetuses exposed to hyperglycemia (which can be influenced by maternal genes) or undernourishment in utero are at increased risk of a large spectrum of growth abnormalities, including developing diabetes in the future [8]. Although such effects could potentially be mediated by methylation and histone modification of the maternal or fetal genome, the phenomenon need not depend on mother-to-offspring transmission of specific disease-associated alleles.

The role of imprinted genes in human disease is incompletely understood, in part because diseaseassociated imprinted genes are difficult to detect by conventional association methods because their effects are dependent on which parent transmitted the risk allele. Notwithstanding these difficulties, recognition of the genetic mechanisms underlying imprinting may have direct relevance to the diagnosis and clinical treatment of the disease (see below). Several comprehensive reviews on imprinting in diseases related to growth and development have recently been published [9-11]. Here, we provide an overview of imprinting as it applies to diabetes.

\section{The biological basis of genetic imprinting}

In diploid organisms, such as humans, all somatic cells have two copies of the genome, one copy inherited from each parent. For the vast majority of autosomal genes, both alleles at each locus influence expression of the gene. However, a small number of genes are imprinted, meaning that gene expression results from only a single allele because the allele transmitted from either the mother or the father is silenced. It is believed that up to $1 \%$ of human genes may be imprinted, and more than 150 imprinted human genes have been identified so far, most of which are related to growth and development $[12,13]$. Imprinted genes can have a significant role in disease because imposition of a functional haploid state at imprinted loci allows a single mutation event to be unopposed, giving it greater potential to affect gene function.

Genomic imprinting is related to the methylation of cytosine bases that occurs primarily in CpG clusters. Such regions are frequently involved in regulation of genes [14]. When DNA is methylated, a hydrogen atom of the cytosine base is replaced with a methyl group [15]. When the methylated region encompasses a gene, the methylated allele is typically not transcribed and thus the methylation leads to gene silencing. Although high levels of methylation (hypermethylation) are generally associated with gene silencing, low levels of DNA methylation (hypomethylation) are generally associated with higher gene activity [14]. Certain genomic regions are characteristically maternally methylated and others paternally methylated, and these are often in close proximity to one another. Typically, if the maternal allele is methylated, only the paternal allele is transcribed. The imprint is normally reset in the germline such that, for example, a female's paternal allele will take on a maternal methylation pattern when passed on to her offspring. Abnormal phenotypes due to incorrect dosage can result if this resetting process fails and imprinted alleles retain the original methylation profile of the parent from whom the allele was transmitted [16]. Although methylation is typically regarded as a silencing mechanism, there are cases in which methylation can also enhance gene expression. For example, methylation of the paternal copy of a region on chromosome 11p15 between the imprinted genes IGF2 (encoding insulin-like growth factor 2) and H19 (an RNA gene) prevents a factor known as an 'insulator' from binding to the region and allows enhancers to access and promote expression of IGF2 on the paternal chromosome [17]. In addition to methylation of DNA, imprinting may also modify gene expression through post-translational modification of histones or activation of microRNAs $[18,19]$. In addition, imprinting is in some cases tissue-specific and/or developmentalperiod-specific [17]. For example, the imprinted gene PLAGL1 (Pleomorphic adenoma gene-like 1, also known as $Z A C$ ), which is involved in transient neonatal diabetes (see below), is imprinted in fibroblasts but not lymphocytes [20].

The molecular modifications associated with methylation are termed 'epigenetic' because they involve changes to DNA structure rather than changes to the DNA sequence. The molecular modifications of DNA associated with genomic imprinting occur in germline cells and, like sequence changes, these modifications can be stably transmitted through several generations of cells or organisms. However, unlike sequence changes, these epigenetic modifications can also be reset, or undone, under appropriate conditions such as during primordial germ cell development [21]. The capability to reset methylation changes is thought to provide flexibility of the body to regulate the timing of gene expression during critical periods of growth and development, and in this light it is not surprising that imprinted genes tend to be found in evolutionarily conserved imprinted domains [21].

Besides genomic imprinting, epigenetic modification can also occur in response to environmental stimuli $[22,23]$, such as parental nutritional status, cigarette smoking, toxins, microbes, endocrine disruptors, chemicals and stress [24]. Although some of these other mechanisms may be transmitted at the organismal level and may also have a role in diabetes, less is known about them. 
Many of the genomic imprinting disorders identified so far in humans affect growth and development $[21,25,26]$. Among the more well known imprinted human disorders are: Prader-Willi and Angelman syndromes, involving deletions and/or inactivations or uniparental disomy (two chromosomal homologs inherited from one parent) of chromosome 15q11-q13; Beckwith-Wiedemann syndrome, involving methylation of genes in the $11 \mathrm{p} 15.5$ region; Russell-Silver syndrome, involving imprinted disturbances of chromosomes 7 or 11; and Albright hereditary osteodystrophy, due to mutations in an imprinted gene on chromosome 20q13.11. Reviews of these disorders have recently been published (for example, $[9,27])$. In recent years, the involvement of imprinting in a sizeable proportion of cases of a rare form of diabetes, neonatal diabetes, has come to be appreciated.

\section{6q24-related transient neonatal diabetes mellitus}

Neonatal diabetes is a rare condition affecting approximately 1 in 100,000 to 1 in 500,000 newborns, with about half being affected permanently and half transiently [28-30]. Approximately $70 \%$ of transient neonatal diabetes mellitus (TNDM) results from abnormalities of a region on chromosome 6q24 containing the imprinted genes PLAGL1 and HYMAI (the RNA gene 'Hydatidiform mole associated and imprinted') [31]. 6q24-related TNDM is characterized by growth retardation and by diabetes developing during the first week of life and lasting, on average, 3 months but in some cases as long as 18 months. There is an elevated risk of diabetes or hyperglycemic episodes occurring later in life. Other features can include macroglossia (large tongue) and umbilical hernia.

\section{The role of imprinting in 6q24-related TNDM}

Approximately $40 \%$ of 6q24-related TNDM cases result from paternal uniparental disomy (UPD; inheritance of two paternal copies rather than one maternal and one paternal copy), usually isodisomy (two identical homologs) of chromosome 6, 40\% from (usually submicroscopic) duplication of the $6 \mathrm{q} 24$ region on the paternally inherited chromosome 6 and 20\% from hypomethylation of the maternal PLAGL1-HYMAI differentially methylated region (DMR). As these two genes are normally silenced by methylation on the maternal homolog and expressed on the paternal homolog during the fetal period, each of these three mechanisms results in twice the normal dosage of these two genes. The mechanism whereby increased dosage at the $6 \mathrm{q} 24$ region leads to hyperglycemia is not well understood, but PLAGL1 has been shown to be involved in apoptosis [20], regulation of insulin secretion [32] and fetal growth [33].

Hypomethylation of the maternal homolog can be caused either by an imprinting mutation in the region containing the maternal PLAGL1 promoter or as part of a generalized 'hypomethylation at imprinted loci' (HIL), the latter at least some of the time inherited in an autosomal recessive manner. More than $50 \%$ of cases of HIL seem to result from recessive mutations in the ZFP57 gene, which encodes a zinc finger protein. The ZFP57 gene is also on chromosome 6 but at $6 \mathrm{p} 22$, essentially unlinked to the PLAGL1-HYMAI region. Among the nine individuals in the seven pedigrees in which ZFP57 mutations were first described [34], all showed, in addition to hypomethylation at the maternal 6q24 DMR, hypomethylation at PEG3 (paternally expressed gene, 19q13) and GRB10 (growth factor receptor-bound protein 10, 7p11-12) DMRs. Some individuals also had hypomethylation of DMRs at PEG1 (17q32), KCNQ1OT1 (an antisense transcript overlapping the potassium-channel-encoding gene $K C N Q 1$ on 11p15), or NESPAS (an antisense transcript to the Novel erythropoiesis stimulating protein gene NESP on 20q13) [34]. As discussed below, single nucleotide polymorphisms (SNPs) at two of these loci (7q32 and 11p15) have been implicated in parent-of-origin-specific associations with T2DM [35]. Association of SNPs within GRB10 with T2DM have also been reported [36,37], although results have been conflicting [38], perhaps in part as a result of lack of examination of parent-of-origin effects.

\section{Clinical and genetic implications of a diagnosis of 6q24-related TNDM}

A clinical diagnosis of TNDM is suspected in infants with severe intrauterine growth retardation, dehydration, hyperglycemia, and hypoinsulinemia without ketoacidosis. The diabetes associated with overexpression at $6 \mathrm{q} 24$ usually resolves by 1 year of age, but children with this genetic subtype are at risk for intermittent hyperglycemic episodes and for developing T2DM, especially at puberty. Affected women may present with gestational diabetes. Children with HIL are at risk for developmental delay.

When 6q24-related TNDM is suspected, a tiered genetic testing approach as summarized in Figure 1 has been suggested by Temple and Mackay [39], who are responsible for much of the research leading to current knowledge about 6q24-related TNDM. This approach can provide information used to assess risks of TNDM to other family members (Table 1 ).

\section{Evidence for a role of imprinting in polygenic diabetes}

Because specific imprinted genes have been associated with syndromes marked by extreme obesity (for example, Prader-Willi) and diabetes (for example, TNDM), it seems likely that there are numerous other imprinted genes having milder effects on obesity and diabetes. Epigenetic regulation and imprinting have been extensively studied in mice [40], although there are substantial 


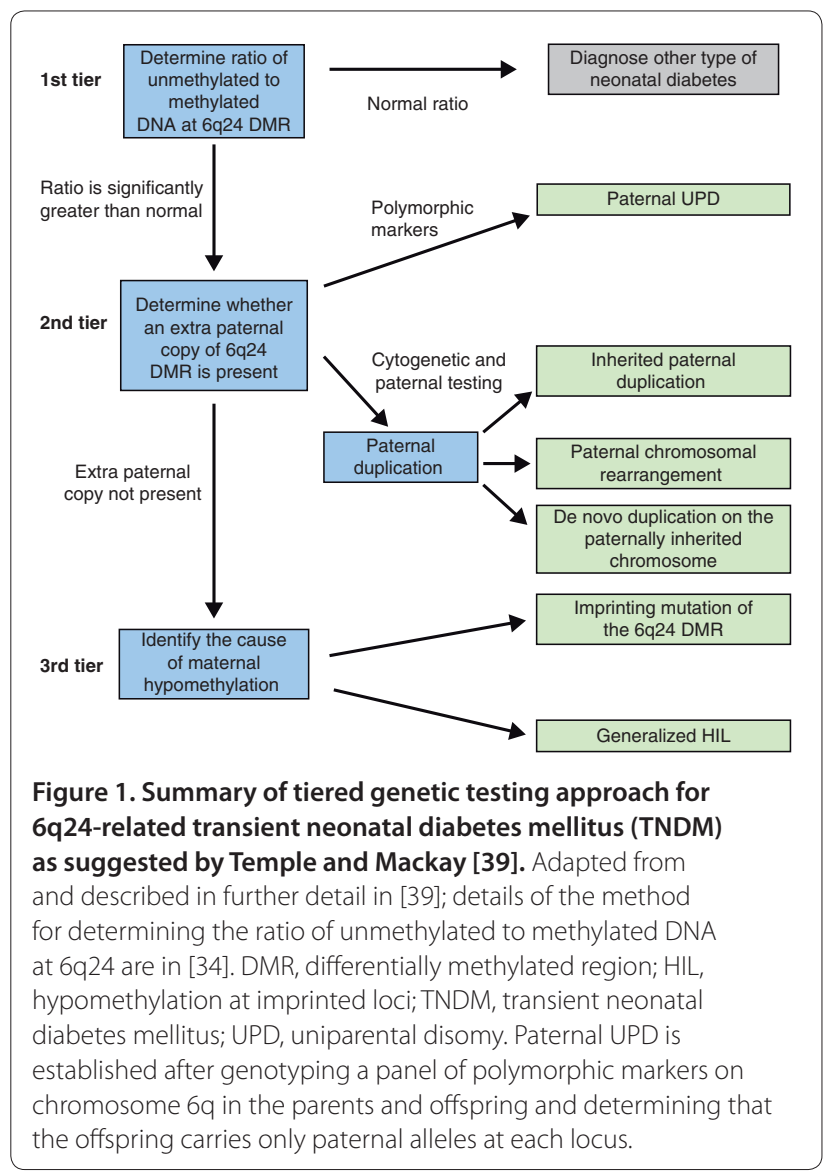

differences in both the numbers and identities of imprinted genes in mice and humans [41], limiting the utility of the mouse model to understand the role of genomic imprinting in humans. Alternative approaches for identifying new imprinted genes in humans have included analysis of large family and population samples using both linkage approaches (for example, [42-46]) and association approaches (for example, [47-49]) that incorporate parent-of-origin effects.

\section{T1DM}

In a genome-wide association study of T1DM, the most strongly associated SNP (rs941576) was found in a well established imprinted region on chromosome 14q32.2 [49]. Additional analyses incorporating parent-of-origin effects were then undertaken that revealed strong evidence for reduced paternal transmission of the protective $\mathrm{G}$ allele at this locus. On the basis of this result, the authors [49] suggested that the causal variant may alter expression of the paternal inherited copy of a nearby gene (possibly $D L K 1$, which encodes Delta-like 1 homolog).

\section{T2DM}

Variants in two imprinted genomic regions (at 11p15 and $7 q 32)$ were identified in a recent study carried out in Icelanders of SNPs in imprinted regions known as being associated with T2DM [35]. None of the variants were impressively associated with T2DM in the standard casecontrol analysis, but in analysis incorporating parent-oforigin effects, there was statistically compelling and independently replicated evidence for association with the maternal allele but not the paternal allele at two SNPs at $11 \mathrm{p} 15$ and one SNP at 7q32. In addition, the paternal C allele at a fourth SNP, rs2334499 on chromosome 11p15, was strongly associated with increased risk for T2DM when paternally inherited ( $\left.\mathrm{OR}=1.41, P=4 \times 10^{-9}\right)$ but moderately associated with decreased risk for T2DM when maternally inherited $(\mathrm{OR}=0.87, P=0.02)$. In addition to the association with diabetes, the authors [35]

\section{Table 1. Risk to other family members for each type of transient neonatal diabetes mellitus}

\begin{tabular}{|c|c|}
\hline Type of TNDM & Risk to other family members \\
\hline Paternal UPD & Unlikely to recur in other family members \\
\hline $\begin{array}{l}\text { Inherited paternal } \\
\text { duplication }\end{array}$ & $\begin{array}{l}\text { The risk to siblings of inheriting the same duplication and being at risk for TNDM and later diabetes is } 50 \% \text {. Offspring of individuals } \\
\text { with duplications are at 50\% risk of inheriting the duplication, but at risk for TNDM or later diabetes if only the allele is inherited } \\
\text { from the father }\end{array}$ \\
\hline $\begin{array}{l}\text { Paternal chromosomal } \\
\text { rearrangement }\end{array}$ & $\begin{array}{l}\text { Risks to family members depend on the particular rearrangement involved. For example, partial trisomy for } 6 q 24 \text { as a result of } \\
\text { unbalanced inheritance of a paternal but not maternal balanced reciprocal translocation would include the TNDM phenotype }\end{array}$ \\
\hline $\begin{array}{l}\text { De novo duplication on } \\
\text { the paternally inherited } \\
\text { chromosome }\end{array}$ & $\begin{array}{l}\text { Some residual risk to siblings owing to the possibility of paternal gonadal or undetected somatic mosaicism for the duplication. } \\
\text { Offspring of individuals with a de novo duplication have a } 50 \% \text { risk of inheriting the duplication, with offspring of males but not } \\
\text { females at risk for TNDM or later diabetes }\end{array}$ \\
\hline $\begin{array}{l}\text { Imprinting mutation of } \\
\text { the } 6 \text { q24 DMR }\end{array}$ & $\begin{array}{l}\text { No familial recurrence has been reported. The causes of these mutations are not well understood and Temple and Mackay consider } \\
\text { testing siblings of affected children for diabetes to be appropriate. The risk to offspring of females with imprinting center mutations } \\
\text { may theoretically be increased but no empirical data are available to support or refute this hypothesis }\end{array}$ \\
\hline Generalized HIL & $\begin{array}{l}\text { Over } 50 \% \text { have homozygosity or compound heterozygosity for ZFP57 mutations as determined by sequencing. There is a } 25 \% \\
\text { recurrence risk in siblings of a child who has inherited two ZFP57 mutations from carrier parents. The penetrance is not known. } \\
\text { The recurrence risk for other forms of HIL is not known because the cause(s) are not known }\end{array}$ \\
\hline
\end{tabular}


also showed that the risk allele at $7 \mathrm{q} 32$ was strongly correlated with reduced expression of nearby candidate gene KLF14 (which encodes the transcription factor Krüppel-like factor 14) in adipose tissue $\left(P=3 \times 10^{-21}\right)$ only when inherited maternally.

\section{Conclusions and clinical implications}

In recent years, efforts to identify imprinted genes have been enhanced greatly by the development of new genome-scale technologies for epigenomic profiling (for example, [50]) and by the cataloguing of known imprinted genes [12,51]. Indeed, epidemiological studies of diabetes and many other complex diseases have begun to consider the role of genetic imprinting and more generally how epigenetic modification can mediate environmental influences on gene expression [52].

As demonstrated by the case of 6q24-related TNDM, knowledge of the role of imprinting in disease has profound implications for recurrence risks in relatives. Using known SNPs to predict risk for polygenic T1DM or T2DM has not yet proven useful in a clinical setting. As the genetic architecture of these diseases continues to be revealed, such prediction may become feasible, and knowledge of the imprinting status of the relevant loci is likely to be an important component of building accurate risk models. Regardless of future clinical usage, paying careful attention to imprinting status clearly enhances the ability to accurately detect associations that will ultimately provide information important for continuing to elucidate the etiology of these complex diseases.

\section{Abbreviations}

DMR, differentially methylated region; HIL, hypomethylation at imprinted loci; T1DM, type 1 diabetes mellitus; T2DM, type 2 diabetes mellitus; TNDM, transient neonatal diabetes mellitus; UPD, uniparental disomy.

\section{Competing interests}

The authors declare that they have no competing interests.

\section{Acknowledgements}

Partial funding for this work was provided by the Mid-Atlantic Nutrition and Obesity Research Center (P30 DK072488)

Published: 23 August 2010

\section{References}

1. Barrett JC, Clayton DG, Concannon P, Akolkar B, Cooper JD, Erlich HA, Julier C, Morahan G, Nerup J, Nierras C, Plagnol V, Pociot F, Schuilenburg H, Smyth DJ, Stevens H, Todd JA, Walker NM, Rich SS: Genome-wide association study and meta-analysis find that over 40 loci affect risk of type 1 diabetes. Nat Genet 2009, 41:703-707.

2. Voight BF, Scott LJ, Steinthorsdottir V, Morris AP, Dina C, Welch RP, Zeggini E, Huth C, Aulchenko YS, Thorleifsson G, McCulloch LJ, Ferreira T, Grallert H, Amin N, Wu G, Willer CJ, Raychaudhuri S, McCarroll SA, Langenberg C, Hofmann OM, Dupuis J, Qi L, Segre AV, van Hoek M, Navarro P, Ardlie K, Balkau $B$, Benediktsson R, Bennett AJ, et al:: Twelve type 2 diabetes susceptibility loci identified through large-scale association analysis. Nat Genet 2010, 42:579-589.

3. Rampersaud E, Mitchell BD, Naj AC, Pollin TI: Investigating parent of origin effects in studies of type 2 diabetes and obesity. Curr Diabetes Rev 2008, 4:329-339.
4. Ballinger SW, Shoffner JM, Hedaya EV, Trounce I, Polak MA, Koontz DA, Wallace DC: Maternally transmitted diabetes and deafness associated with a 10.4 kb mitochondrial DNA deletion. Nat Genet 1992, 1:11-15.

5. van den Ouweland JM, Bruining GJ, Lindhout D, Wit JM, Veldhuyzen BF, Maassen JA: Mutations in mitochondrial tRNA genes: non-linkage with syndromes of Wolfram and chronic progressive external ophthalmoplegia. Nucleic Acids Res 1992, 20:679-682.

6. Guillausseau PJ, Massin P, Dubois-LaForgue D, Timsit J, Virally M, Gin H, Bertin E, Blickle JF, Bouhanick B, Cahen J, Caillat-Zucman S, Charpentier G, Chedin P, Derrien C, Ducluzeau PH, Grimaldi A, Guerci B, Kaloustian E, Murat A, Olivier F, Paques M, Paquis-Flucklinger V, Porokhov B, Samuel-Lajeunesse J, Vialettes B: Maternally inherited diabetes and deafness: a multicenter study. Ann Intern Med 2001, 134:721-728.

7. Murphy R, Turnbull DM, Walker M, Hattersley AT: Clinical features, diagnosis and management of maternally inherited diabetes and deafness (MIDD) associated with the $3243 \mathrm{~A}>\mathrm{G}$ mitochondrial point mutation. Diabet Med 2008, 25:383-399.

8. Hales CN, Barker DJ: Type 2 (non-insulin-dependent) diabetes mellitus: the thrifty phenotype hypothesis. Diabetologia 1992, 35:595-601.

9. Butler MG: Genomic imprinting disorders in humans: a mini-review. J Assist Reprod Genet 2009, 26:477-486.

10. Stoger R: Epigenetics and obesity. Pharmacogenomics 2008, 9:1851-1860.

11. Weinstein LS, Xie T, Qasem A, Wang J, Chen M: The role of GNAS and other imprinted genes in the development of obesity. Int J Obes (Lond) 2010, 34:6-17.

12. Morison IM, Ramsay JP, Spencer HG: A census of mammalian imprinting. Trends Genet 2005, 21:457-465.

13. Luedi PP, Dietrich FS, Weidman JR, Bosko JM, Jirtle RL, Hartemink AJ: Computational and experimental identification of novel human imprinted genes. Genome Res 2007, 17:1723-1730.

14. Suzuki MM, Bird A: DNA methylation landscapes: provocative insights from epigenomics. Nat Rev Genet 2008, 9:465-476.

15. Bock C, Lengauer T: Computational epigenetics. Bioinformatics 2008, 24:1-10.

16. Kelsey G: Genomic imprinting - roles and regulation in development. Endocr Dev 2007, 12:99-112.

17. Ideraabdullah FY, Vigneau S, Bartolomei MS: Genomic imprinting mechanisms in mammals. Mutat Res 2008, 647:77-85.

18. Wolffe AP, Matzke MA: Epigenetics: regulation through repression. Science 1999, 286:481-486

19. van Vliet J, Oates NA, Whitelaw E: Epigenetic mechanisms in the context of complex diseases. Cell Mol Life Sci 2007, 64:1531-1538.

20. Mackay DJ, Coupe AM, Shield JP, Storr JN, Temple IK, Robinson DO: Relaxation of imprinted expression of ZAC and HYMAI in a patient with transient neonatal diabetes mellitus. Hum Genet 2002, 110:139-144.

21. Hitchins MP, Moore GE: Genomic imprinting in fetal growth and development. Expert Rev Mol Med 2002, 4:1-19.

22. Jirtle RL, Skinner MK: Environmental epigenomics and disease susceptibility. Nat Rev Genet 2007, 8:253-262

23. Feinberg AP: Phenotypic plasticity and the epigenetics of human disease. Nature 2007, 447:433-440

24. MacFarlane AJ, Strom A, Scott FW: Epigenetics: deciphering how environmental factors may modify autoimmune type 1 diabetes. Mamm Genome 2009, 20:624-632.

25. Abu-Amero S, Monk D, Apostolidou S, Stanier P, Moore G: Imprinted genes and their role in human fetal growth. Cytogenet Genome Res 2006, 113:262-270.

26. Giannoukakis N, Deal C, Paquette J, Goodyer CG, Polychronakos C: Parental genomic imprinting of the human IGF2 gene. Nat Genet 1993, 4:98-101.

27. Horsthemke B, Wagstaff J: Mechanisms of imprinting of the Prader-Willi/ Angelman region. Am J Med Genet A 2008, 146A:2041-2052.

28. von Muhlendahl KE, Herkenhoff $\mathrm{H}$ : Long-term course of neonatal diabetes. N Engl J Med 1995, 333:704-708.

29. Shield JP, Gardner RJ, Wadsworth EJ, Whiteford ML, James RS, Robinson DO, Baum JD, Temple IK: Aetiopathology and genetic basis of neonatal diabetes. Arch Dis Child Fetal Neonatal Ed 1997, 76:F39-F42.

30. Slingerland AS, Shields BM, Flanagan SE, Bruining GJ, Noordam K, Gach A, Mlynarski W, Malecki MT, Hattersley AT, Ellard S: Referral rates for diagnostic testing support an incidence of permanent neonatal diabetes in three European countries of at least 1 in 260,000 live births. Diabetologia 2009, 52:1683-1685. 
31. Flanagan SE, Patch AM, Mackay DJ, Edghill EL, Gloyn AL, Robinson D, Shield JP, Temple K, Ellard S, Hattersley AT: Mutations in ATP-sensitive K+ channel genes cause transient neonatal diabetes and permanent diabetes in childhood or adulthood. Diabetes 2007, 56:1930-1937.

32. Arima T, Kamikihara T, Hayashida T, Kato K, Inoue T, Shirayoshi Y, Oshimura M, Soejima H, Mukai T, Wake N: ZAC, LIT1 (KCNQ1OT1) and p57KIP2 (CDKN1C) are in an imprinted gene network that may play a role in BeckwithWiedemann syndrome. Nucleic Acids Res 2005, 33:2650-2660.

33. Varrault A, Gueydan C, Delalbre A, Bellmann A, Houssami S, Aknin C, Severac D, Chotard L, Kahli M, Le Digarcher A, Pavlidis P, Journot L: Zac1 regulates an imprinted gene network critically involved in the control of embryonic growth. Dev Cell 2006, 11:711-722.

34. Mackay DJ, Callaway JL, Marks SM, White HE, Acerini CL, Boonen SE, Dayanikli P, Firth HV, Goodship JA, Haemers AP, Hahnemann JM, Kordonouri O, Masoud AF, Oestergaard E, Storr J, Ellard S, Hattersley AT, Robinson DO, Temple IK: Hypomethylation of multiple imprinted loci in individuals with transient neonatal diabetes is associated with mutations in ZFP57. Nat Genet 2008, 40:949-951.

35. Kong A, Steinthorsdottir V, Masson G, Thorleifsson G, Sulem P, Besenbacher S, Jonasdottir A, Sigurdsson A, Kristinsson KT, Frigge ML, Gylfason A, Olason PI, Gudjonsson SA, Sverrisson S, Stacey SN, Sigurgeirsson B, Benediktsdottir KR, Sigurdsson $\mathrm{H}$, Jonsson T, Benediktsson R, Olafsson JH, Johannsson OT, Hreidarsson AB, Sigurdsson G, Ferguson-Smith AC, Gudbjartsson DF, Thorsteinsdottir U, Stefansson K: Parental origin of sequence variants associated with complex diseases. Nature 2009, 462:868-874

36. Di Paola R, Ciociola E, Boonyasrisawat W, Nolan D, Duffy J, Miscio G, Cisternino C, Fini G, Tassi V, Doria A, Trischitta V: Association of hGrb10 genetic variations with type 2 diabetes in Caucasian subjects. Diabetes Care 2006, 29:1181-1183

37. Rampersaud E, Damcott CM, Fu M, Shen H, McArdle P, Shi X, Shelton J, Yin J, Chang YP, Ott SH, Zhang L, Zhao Y, Mitchell BD, O'Connell J, Shuldiner AR: Identification of novel candidate genes for type 2 diabetes from a genome-wide association scan in the Old Order Amish: evidence for replication from diabetes-related quantitative traits and from independent populations. Diabetes 2007, 56:3053-3062.

38. Di Paola R, Wojcik J, Succurro E, Marucci A, Chandalia M, Padovano L, Powers C, Merla G, Abate N, Sesti G, Doria A, Trischitta V: GRB10 gene and type 2 diabetes in Whites. J Intern Med 2010, 267:132-133.

39. Temple IK, Mackay DJG: Diabetes mellitus, 6q24-related transient neonatal. In GeneReviews. Edited by Pagon RA, Bird TC, Dolan CR, Stephens K. Seattle: University of Washington; 2005 (updated 2010) [http://www.ncbi.nlm.nih. gov/bookshelf/br.fcgi?book=gene\&part=dmtn]

40. Wood AJ, Oakey RJ: Genomic imprinting in mammals: emerging themes and established theories. PLoS Genet 2006, 2:e147.

41. Monk D, Arnaud P, Apostolidou S, Hills FA, Kelsey G, Stanier P, Feil R, Moore GE: Limited evolutionary conservation of imprinting in the human placenta. Proc Natl Acad Sci USA 2006, 103:6623-6628.
42. Lindsay RS, Kobes S, Knowler WC, Bennett PH, Hanson RL: Genome-wide linkage analysis assessing parent-of-origin effects in the inheritance of type 2 diabetes and BMI in Pima Indians. Diabetes 2001, 50:2850-2857.

43. Dong C, Li WD, Geller F, Lei L, Li D, Gorlova OY, Hebebrand J, Amos Cl, Nicholls RD, Price RA: Possible genomic imprinting of three human obesity-related genetic loci. Am J Hum Genet 2005, 76:427-437.

44. Gorlova OY, Amos Cl, Wang NW, Shete S, Turner ST, Boerwinkle E: Genetic linkage and imprinting effects on body mass index in children and young adults. Eur J Hum Genet 2003, 11:425-432.

45. Guo YF, Shen H, Liu YJ, Wang W, Xiong DH, Xiao P, Liu YZ, Zhao LJ, Recker RR, Deng HW: Assessment of genetic linkage and parent-of-origin effects on obesity. J Clin Endocrinol Metab 2006, 91:4001-4005.

46. Reynisdottir I, Thorleifsson G, Benediktsson R, Sigurdsson G, Emilsson V, Einarsdottir AS, Hjorleifsdottir EE, Orlygsdottir GT, Bjornsdottir GT, Saemundsdottir J, Halldorsson S, Hrafnkelsdottir S, Sigurjonsdottir SB, Steinsdottir S, Martin M, Kochan JP, Rhees BK, Grant SF, Frigge ML, Kong A, Gudnason V, Stefansson K, Gulcher JR: Localization of a susceptibility gene for type 2 diabetes to chromosome 5q34-q35.2. Am J Hum Genet 2003, 73:323-335.

47. Huxtable SJ, Saker PJ, Haddad L, Walker M, Frayling TM, Levy JC, Hitman GA O'Rahilly S, Hattersley AT, McCarthy MI: Analysis of parent-offspring trios provides evidence for linkage and association between the insulin gene and type 2 diabetes mediated exclusively through paternally transmitted class III variable number tandem repeat alleles. Diabetes 2000, 49:126-130.

48. Klupa T, Warram JH, Antonellis A, Pezzolesi M, Nam M, Malecki MT, Doria A, Rich SS, Krolewski AS: Determinants of the development of diabetes (maturity-onset diabetes of the young-3) in carriers of HNF-1alpha mutations: evidence for parent-of-origin effect. Diabetes Care 2002, 25:2292-2301.

49. Wallace C, Smyth DJ, Maisuria-Armer M, Walker NM, Todd JA, Clayton DG: The imprinted DLK1-MEG3 gene region on chromosome 14q32.2 alters susceptibility to type 1 diabetes. Nat Genet 2010, 42:68-71.

50. Feinberg AP: Genome-scale approaches to the epigenetics of common human disease. Virchows Arch 2010, 456:13-21.

51. Morison IM, Paton CJ, Cleverley SD: The imprinted gene and parent-oforigin effect database. Nucleic Acids Res 2001, 29:275-276.

52. Foley DL, Craig JM, Morley R, Olsson CA, Dwyer T, Smith K, Saffery R: Prospects for epigenetic epidemiology. Am J Epidemio/ 2009, 169:389-400.

doi:10.1186/gm176

Cite this article as: Mitchell BD, Pollin TI: Genomic imprinting in diabetes. Genome Medicine 2010, 2:55. 